Council, $£ 1,977,450$ for agricultural education and research under the Ministry of Agriculture and Fisheries, and $£ 412,652$ for agricultural research and experiments under the Department of Agriculture for Scotland; $£ 144,450$ for fisheries research, $£ 374,000$ for forestry research and education, $£ 78,623$ for fisheries research and development in Scotland, $£ 500,000$ for Colonial research, and $£ 50,000$ for the social survey. Miscellaneous grants in aid of scientific investigation include $£ 53,000$ to the Royal Society. The grand total is approximately $£ 19,500,000$. Although the Dominions Office vote includes a grant of $£ 33,825$ in aid of Imperial Economic and Research Services, and the Ministry of Food vote $£ 4,500,000$ for the production of ground-nuts in East and Central Africa, of which some small fraction is for research, it is unlikely that the total expenditure from the Exchequer in aid of civil research much exceeds $£ 10,000,000$ for the current year as against the $£ 60,000,000$ to be expended by the Ministry of Supply and the Admiralty, apart from the work which may be carried out by the Department of Scientific and Industrial Research for the Services.

\section{Atomic Power in Sweden}

THE Swedish Atomic Committee, which consists of ten leading men of science and technicians, has submitted a proposal to the Swedish Government, recommending the formation as soon as possible of a joint-stock company, AB Atomenergi, with a capital of about $£ 241,000$, of which about two thirds would be contributed by the State and the remainder by Swedish industry. The first task of the company would be to design and build an experimental plant for the liberation of atomic energy, and later on a plant for the production of atomic power on an industrial scale would be erected. The Committee also suggests that, in addition to 2,000,000 kronor already proposed in the current State budget, another $2,000,000$ kronor should be appropriated for research work to be performed under the supervision of a new body, the Atomic Research Council. It is reported that the company will use uranium from shale deposits in the central Swedish provinces of Närke and Västergötland.

\section{Suggested British Herpetological Society}

Ax an informal meeting held at the British Museum (Natural History) on April 10 the formation of a British Herpetological Society was considered. The Society would be formed with the view of increasing our present knowledge and promoting interest in various aspects of herpetology which, it is felt, have been somewhat neglected. Its main objects would be : (1) to encourage the study of the ecology, lifehistories, habits and distribution of the Amphibia and reptiles, and of the British species in particular ; (2) to publish annually a report on the work of the Society, and to review briefly advances in knowledge, particularly in the field of ecology; (3) to hold meetings, when possible, for the reading of papers and the discussion of problems relating to herpetology; (4) to record and compile information on the various aspects of the subject covered by the Society. Although such a Society would, of necessity, be concerned mainly with the study of British species, foreign membership would be most welcome. It is suggested that the annual subscription to the Society, including a free copy of the report, should be ten shillings. Those interested in the formation of such a Society should communicate with Capt. J. D.
Romer, 96 Mortlake Road, Kew, Surrey. If the response is sufficiently large, further steps will be taken to inaugurate the Society, and individuals will be informed accordingly.

\section{Association of Social Anthropologists}

AN Association of Social Anthropologists was founded on July 23,1946 , in response to the general opinion among social anthropologists in Great Britain that the subject has reached a stage of development warranting the establishment of a professional organisation. Its objects are to promote the study and teaching of social anthropology as a specialized branch of anthropology; to represent the interests and maintain the professional standards of the subject ; to arrange periodic conferences of the members of the Association; and to secure publication of researches under its auspices. It is intended to publish a journal, Annals of Social Anthropology, as soon as arrangements can be made.

The Association includes teachers and senior research workers in social anthropology in the British Empire. Membership is limited to persons holding, or having held, a teaching or research appointment in social anthropology, and is strictly by invitation of the officers and committee of the Association. The present officers and committee are: Prof. A. R. Radcliffe-Brown (president), Prof. E. E. EvansPritchard (chairman and hon. secretary), Prof. Raymond Firth, Prof. C. Daryll Forde and Dr. Meyer Fortes.

\section{Iraq Natural History Museum}

THE first Natural History Museum in. Iraq, which is under the auspices of the Iraqi Ministry of Education, was established early in 1946. The formal opening by the Regent of Iraq took place on May 2, 1946. The Museum consists of three main departments at present. (1) Zoological Department : the present exhibits in this department represent most of the avifauna of Iráq, as well as small collections of Iraqi mammals, reptiles, fishes and invertebrates. (2) Botanical Department: in this department plaster models of Iraqi fruits and vegetables are exhibited. There are also specimens of plant products, economic plants, plant diseases, etc. (3) Geological Department : in this department two of the oil companies operating in the country have participated in presenting its exhibits. The Iraq Petroleum Co. presented a cement model of the geological structure of the Kirkuk oilfields, as well as specimens of rocks, crude oil, and fossils found in Iraq. The Rafidain Oil Co. presented a model of an oil refinery, specimens of oil products, a model of a Leyland motor oil-tanker, a lubricating oil unit, a petrol filling pump, and various photographs and diagrams. The Museum is seeking to establish contacts with similar museums elsewhere, and to exchange information and publications with them. All communications should be addressed to the Director, Iraq Natural History Museum, Baghdad, Iraq.

\section{British Society for the History of Science}

AT the first annual general meeting of the British Society for the History of Science, held in the rooms of the Royal Society on May 5, the following elections of officers and council were made: President, Dr. Charles Singer; Vice-Presidents, Prof. H. Dingle, Dr. E. J. Holmyard, Sir Arthur MacNalty, Prof. J. R. Partington, Mrs. Charles Singer, Dr. Sherwood 